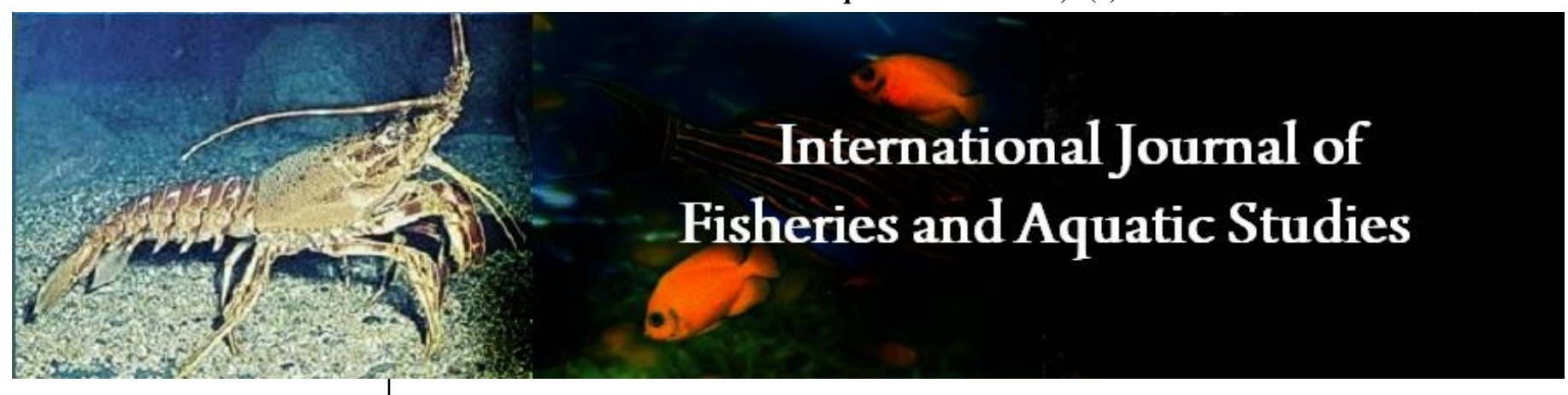

E-ISSN: 2347-5129

P-ISSN: 2394-0506

(ICV-Poland) Impact Value: 5.62

(GIF) Impact Factor: 0.549

IJFAS 2021; 9(5): 116-123

(C) 2021 IJFAS

www.fisheriesjournal.com

Received: 10-06-2021

Accepted: 16-08-2021

N'guessan Koffi Richard

Laboratoire des Milieux Naturels

et Conservation de la

Biodiversité, UFR Biosciences,

Université Félix-Houphouët-

Boigny, 22 BP 582 Abidjan, Côte d'Ivoire

KIEN Kouassi Brahiman

UFR Sciences Biologiques,

Université Péléforo GON

COULIBALY, BP 1328

Korhogo, Côte d'Ivoire

BEDIA Aké Théophile

Laboratoire des Milieux Naturels

et Conservation de la

Biodiversité, UFR Biosciences,

Université Félix-Houphouët-

Boigny, 22 BP 582 Abidjan, Côte

d'Ivoire

Corresponding Author:

N'guessan Koffi Richard

Laboratoire des Milieux Naturels

et Conservation de la

Biodiversité, UFR Biosciences,

Université Félix-Houphouët-

Boigny, 22 BP 582 Abidjan, Côte

d'Ivoire

\section{Characterization of the production factors of the fishing industry and specific diversity in the Aghien lagoon (Ivory Coast)}

\section{BEDIA Aké Théophile, KIEN Kouassi Brahiman and N'guessan Koffi Richard}

DOI: $\underline{\text { https://doi.org/10.22271/fish.2021.v9.i5b.2575 }}$

\section{Abstract}

The study of fishing activity on the Aghien Lagoon (Ivory Coast, West Africa), conducted from April 2019 to May 2020 identified 402 fishermen. This population is composed of Ivorians (73.38\%) and foreigners $(26.62 \%)$. The fishing activity is controlled by two categories of fishermen: professionals who only fish $(42.53 \%)$ and occasional fishermen with an accessory activity $(57.47 \%)$. Ivorian fishermen are mostly farmer-fishermen. The fishing activity is dominated in this lagoon by adults between 30 and 45 years old $(48.26 \%)$. These fishermen have a high literacy rate $(73 \%)$. The fishing techniques used in this lagoon are pots, hawks, gillnets, longlines, beach seines and bamboo traps. The high presence of Chrysichthys nigrodigitatus in the catches of all the gears could lead to an imbalance in this ecosystem containing 45 species divided into 25 families and 8 orders.

Keywords: Aghien lagoon, artisanal fishing, fishing gear, Ivory Coast

\section{Introduction}

Lagoon fishing contributes to food and nutritional security without forgetting the monetary income and other socio-cultural utilities that it brings to the populations living in the rivers and lakes ${ }^{[1]}$. Thus, it constitutes an economic stake for these riparian communities ${ }^{[2]}$. In Ivory Coast, fishing activity is carried out by fishermen, fishmongers and smokers who play an important role in the development of fishery products ${ }^{[3]}$. Artisanal fishing therefore appears to be well structured, but the lack of information at certain stages constitutes a handicap in the development and conduct of development and management plans for this sector of activity ${ }^{[4]}$. The Aghien lagoon is no exception to this situation insofar as the work carried out on this lagoon show that no rational management plan has been formulated for this body of water ${ }^{[5]}$. This study on characterization of the production factors of the fishing is part of a series of works aimed at establishing a database on the fishing activity practiced in the lagoons of Ivory Coast with a view to a management plan for these water bodies. It was carried out on the Aghien lagoon in order to deepen knowledge about fishing in this lagoon. It attempts to describe the organization of fishermen, on the one hand; the machines, their techniques of use and their selectivity on the Aghien lagoon, on the other hand.

\section{Materials and Methods}

\subsection{Description of the Study Area}

The works were carried out on the Aghien lagoon in the locality of Akouyaté located between $5^{\circ} 20^{\prime}-5^{\circ} 30$ ' $\mathrm{N}$ and $3^{\circ} 50^{\prime}-4^{\circ} 00^{\prime} \mathrm{W}$ (figure 1 )

\subsection{Sampling collection}

Daily monitoring of fishing activities on the Aghien Lagoon through surveys at selected sites in the study area were conducted during this study. The technique of data collection has 3 components. The survey by questionnaire which consisted of administering to each fisherman, a questionnaire for information concerning the civil status of the fisherman, his nationality, his level of education, his fishing gear and their selectivity and his activities related to fishing. The interview survey, which consisted of questioning the fishermen about the functioning of the fish sector in the study area. The direct observation of the facts, which consisted of following 
the actors in their different activities, allowed for the verification of the information collected from the questionnaires. The criteria for classifying fishermen, based on nationality and ethnicity, time spent fishing and the distribution of fishermen by age group are inspired ${ }^{[6-8]}$. The distribution of fishermen by level of education is done according to Boguhé et al. (2011) ${ }^{[9]}$. The data obtained were processed with Excel soft.

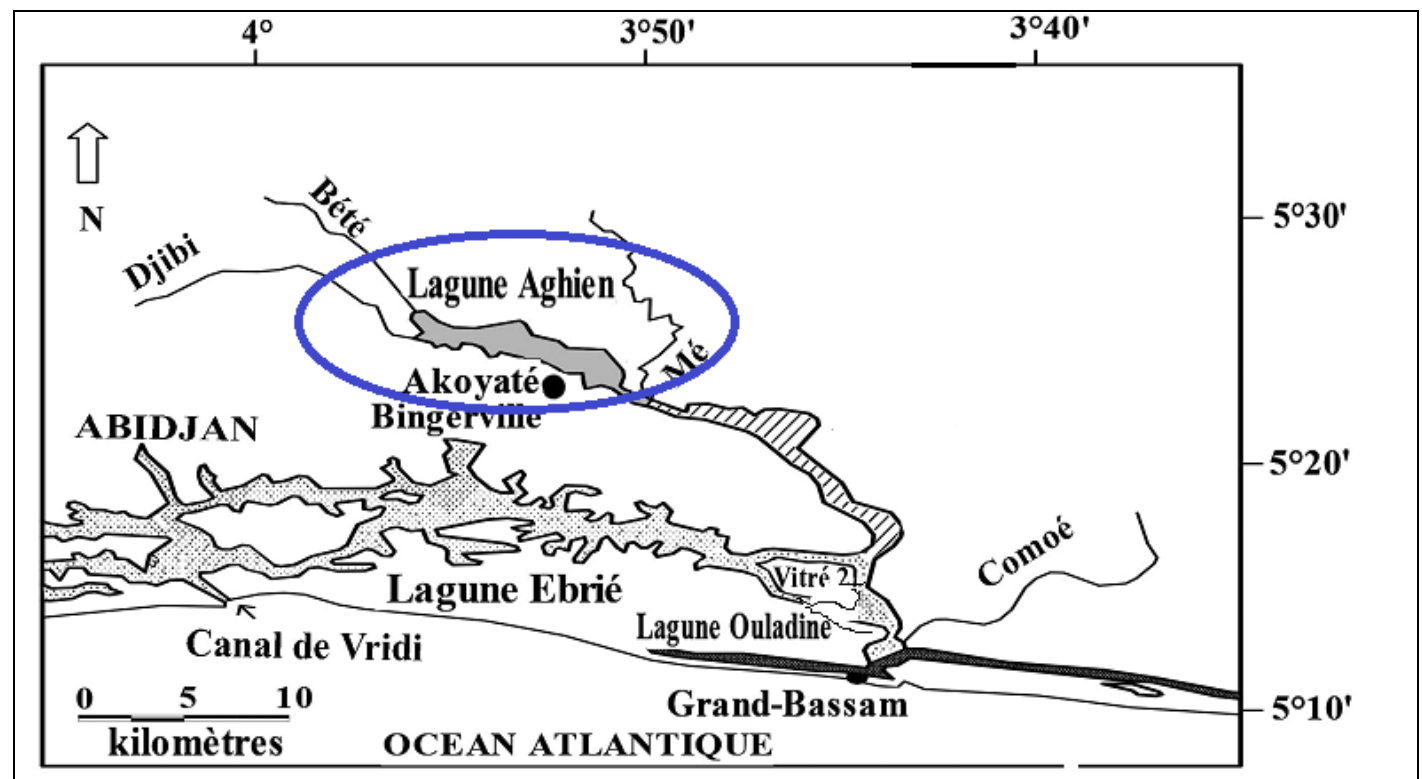

Fig 1: Geographical location of the survey stations $(\bullet)$ on the Aghien Lagoon

\section{Results}

\subsection{Fishers}

\subsubsection{Nationalities}

A total of 402 fishermen were counted on the Aghien Lagoon between April 2019 and May 2020. This workforce is made up of 295 Ivorians (73.38\%) and 107 foreigners all Togolese (26.62\%) (Figure 2).

\subsubsection{Age range}

The dominant age group in the population of fishermen surveyed is adults between the ages of 30 and $45(48.26 \%)$. Older people $(26.62 \%)$ outnumber younger people $(25.12 \%)$ in this population (Figure 3 ).

\subsubsection{Study level}

The fishermen of the Aghien Lagoon who have a level of education $(73 \%)$ are more numerous than the illiterate $(27 \%)$. Figure 4 presents the distribution of literate fishermen according to the level of education. Fishermen with secondary education $(49 \%)$ are more represented than those with primary education $(24 \%)$.

\subsubsection{Professional category}

Two categories of fishermen have been identified throughout the Aghien Lagoon (Figure 5). These are: -professional fishermen who are the least numerous (42.53\%). These are individuals who have only fishing as an activity and practice it all year round. -Occasional fishermen (57.47\%), who fish to meet their food needs or to solve a specific financial problem, are the most present in this population. They combine fishing with other income-generating activities. They are mostly Ivorians. The majority of fishermen $(88 \%)$ carry out their activity individually. Collective fishing accounts for $12 \%$ of this population.

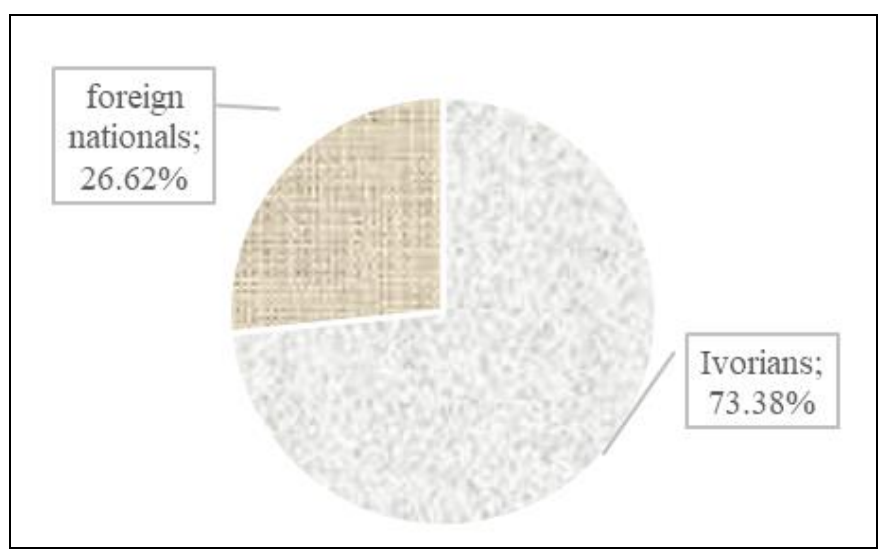

Fig 2: Distribution of fishermen identified on the Aghien lagoon from April 2019 to March 2020 by nationality

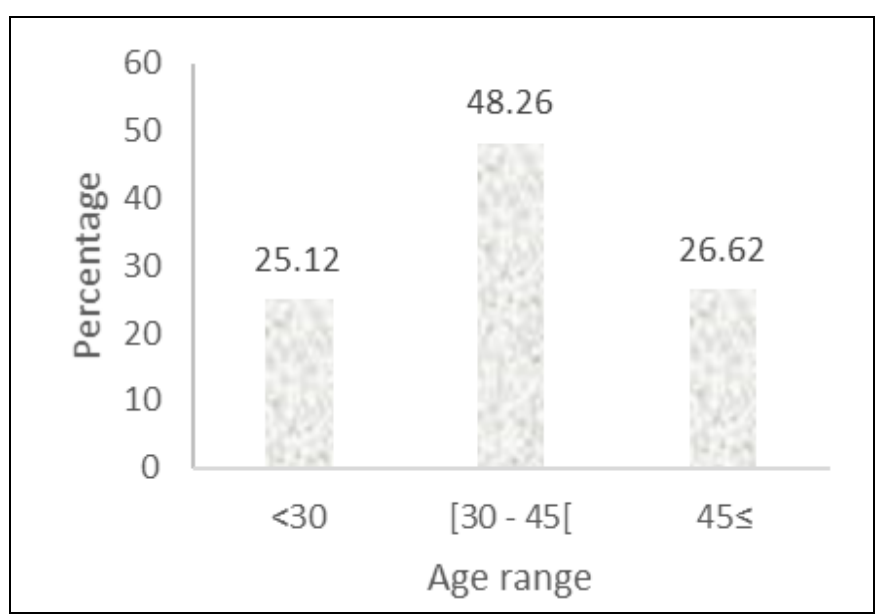

Fig 3: Distribution of fishermen identified on the Aghien lagoon from April 2019 to March 2020 by age range. 


\subsubsection{Activities related to fishing}

The activities related to fishing, carried out by the fishermen on the Aghien lagoon are summarized in Table 1. In general, fishermen associate agriculture with fishing (50.50\%). They are divided between $49.25 \%$ Ivorians and $1.25 \%$ foreigners. Only the Ivorians associate fishing with trade (06.22\%), fish farming $(00.5 \%)$, agriculture and sewing (00.25\%).

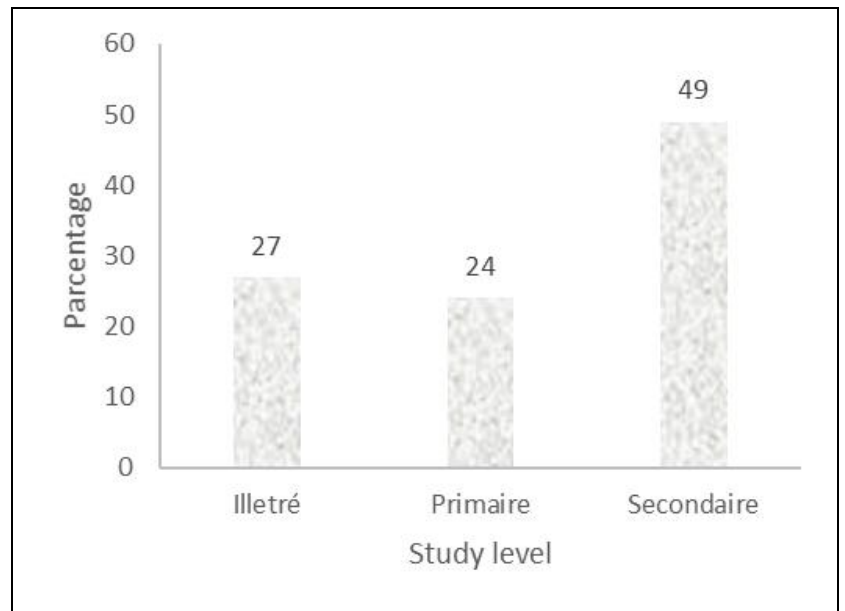

Fig 4: Distribution of fishermen identified on the Aghien Lagoon from April 2019 to March 2020 by study level

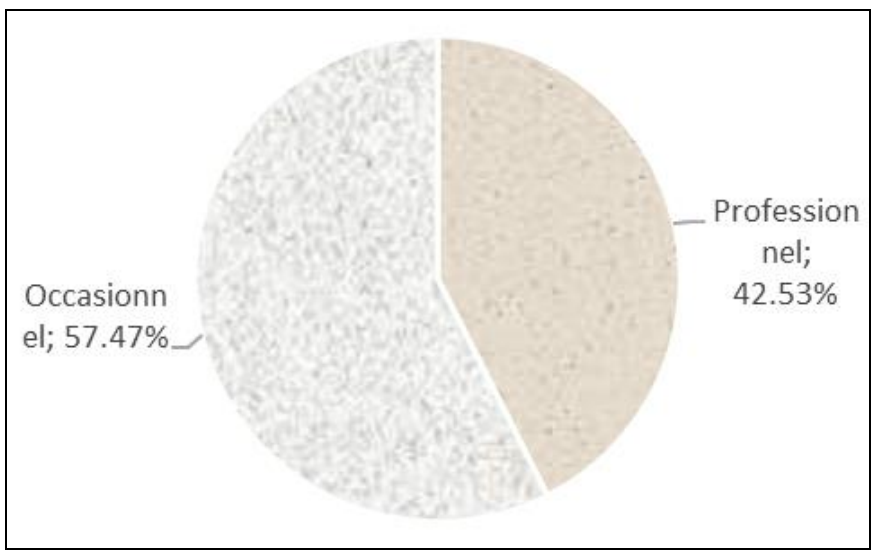

Fig 5: Distribution of fishermen identified on the Aghien Lagoon from April 2019 to March 2020 by occupational categories

\subsubsection{Fishing equipment}

\subsubsection{Inventory and utilization rates}

Six types of fishing gear are used by fishermen (Table 2). These are long lines, pots, bamboo traps, gill nets, beach seines and hawksbills. It appears from this table that professional fishermen use more gill nets $(51.46 \%)$, longlines $(17.54 \%)$ and pots $(16.34 \%)$. The occasional fishermen prefer, in decreasing order, gill nets $(94.37 \%)$, bamboo traps (91.77\%), longlines $(89.61 \%)$ and pots $(88.31 \%)$

Table 1: Activities identified among fishing communities in Aghien Lagoon from April 2019 to March 2020.

\begin{tabular}{|c|c|c|c|c|}
\hline & \multicolumn{2}{|c|}{ Ivorian } & \multicolumn{2}{c|}{ Foreigners } \\
\hline Activités & Number & Percentage & Number & Percentage \\
\hline Fishing only & 69 & 17,16 & 102 & 25,37 \\
\hline Fishing + Agriculture & 198 & 49,25 & 5 & 01,25 \\
\hline Fishing + Trading & 25 & 6,22 & 0 & 0 \\
\hline Fishing + Fish Farming & 2 & 00,5 & 0 & 0 \\
\hline Fishing + Agriculture + Sewing & 1 & 00,25 & 0 & 0 \\
\hline Total & 295 & 73,38 & 107 & 26,62 \\
\hline
\end{tabular}

Table 2: Inventory of fishing gear used by artisanal fishers on the Aghien lagoon, from April 2004 to March 2006

\begin{tabular}{|c|c|c|}
\hline & Professional fishers & Occasional fishers \\
\hline Fishing gear & Rate utilization $(\%)$ & Rate utilization $(\%)$ \\
\hline Longlines & 17,54 & 89,61 \\
\hline Fishnets & 16,34 & 88,31 \\
\hline Bamboo trap & 5,26 & 91,77 \\
\hline Fishnets & 51,46 & 94,37 \\
\hline Beach seines & 1,75 & 00,43 \\
\hline Éperviers & 5,26 & 09,96 \\
\hline
\end{tabular}

\subsubsection{Sélectivité}

The fishing gears used on the Aghien lagoon are in most cases, selective. Selective gear is defined as gear that catches essentially one or two types of fish, without excluding the others. This can be seen in Table 3 .

Table 3: Gear selectivity

\begin{tabular}{|c|c|c|c|c|c|c|c|c|}
\hline & \multirow{2}{*}{ Longlines } & \multirow{2}{*}{ Fishnets } & \multirow{2}{*}{ Bamboo trap } & \multicolumn{3}{|c|}{ Fishnets } & \multirow{2}{*}{ Beach seines } & \multirow{2}{*}{ Éperviers } \\
\hline & & & & Sm & Mm & $\mathbf{L m}$ & & \\
\hline Chrysichthys maurus & $\mathrm{X}$ & $\mathrm{X}$ & $\mathrm{X}$ & & & $\mathrm{X}$ & & \\
\hline Chrysichthys nigrodigitatus & & $\mathrm{X}$ & $\mathrm{X}$ & & & & & \\
\hline Pomadasys jubelini & $\mathrm{X}$ & & & & & & & \\
\hline Polydactylus quadrifilis & & & & & & $\mathrm{X}$ & & \\
\hline Sarotherodon melanotheron & & & & & $\mathrm{X}$ & & & \\
\hline Tilapia guineensis & & & & & $\mathrm{X}$ & & & $\mathrm{X}$ \\
\hline Tylochromis jentinki jintinki & & & & & & & & $\mathrm{X}$ \\
\hline All species included & & & & $\mathrm{X}$ & & & $\mathrm{X}$ & \\
\hline
\end{tabular}

$\mathrm{Sm}=$ small mesh; $\mathrm{Mm}=$ Medium mesh; $\mathrm{Lm}=$ Large mesh 
The small mesh nets $(10 \mathrm{~mm}$ to $30 \mathrm{~mm})$ catch all small fish. Those of medium mesh $(30 \mathrm{~mm}$ to $50 \mathrm{~mm}$ ) catch mainly Tilapia guineensis and Sarotherodon melanotheron. Those of large mesh (50 mm and more) catch essentially Polydactylus quadrifilis and Chrysichthys maurus.

For the hawksbills, the gears are made for Tylochromis jentinki jintinki and Tilapia guineensis. Concerning the longlines, the targeted species are Chrysichthys maurus and Pomadasys jubelini.

The predominant species caught by the creels are
Chrysichthys nigrodigitatus and Chrysichthys maurus. The bamboo traps catch exclusively Chrysichthys maurus and Chrysichthys nigrodigitatus. The beach seines capture all species regardless of size.

\subsubsection{Captures}

\subsubsection{Specific richness}

The present study identified 45 species in 25 families and 8 orders (Table 4).

Table 4: Orders, families, and species of fish sampled in Aghien Lagoon from April 2019 to March 2020.

\begin{tabular}{|c|c|c|}
\hline Order & Family & Species \\
\hline \multirow[t]{4}{*}{ Osteoglossiformes } & Notopteridae & Papyrocranus afer \\
\hline & Mormyridae & Marcusenius furcidens \\
\hline & & Marcusenius ussheri \\
\hline & & Petrocephalus bovei \\
\hline Elopiformes & Elopidae & Elops lacerta \\
\hline \multirow[t]{2}{*}{ Clupeiformes } & Clupeidae & Ethmalosa fimbriata \\
\hline & & Pellonula leonensis \\
\hline \multirow[t]{4}{*}{ Characiformes } & Distichodontidae & Distichodus rostratus \\
\hline & Alestidae & Brycinus longipinnis \\
\hline & & Brycinus nurse \\
\hline & Hepsetidae & Hepsetus odoe \\
\hline \multirow[t]{10}{*}{ Siluriformes } & Schilbeidae & Parailia pellucida \\
\hline & & Schilbe mystus \\
\hline & Clariidae & Clarias ebriensis \\
\hline & & Clarias gariepinus \\
\hline & & Heterobranchus isopterus \\
\hline & & Heterobranchus longifilis \\
\hline & Claroteidae & Chrysichthys auratus \\
\hline & & Chrysichthys maurus \\
\hline & & Chrysichthys nigrodigitatus \\
\hline & Mochokidae & Synodontis bastiani \\
\hline Beloniformes & Hemiramphidae & Hemiramphus balao \\
\hline \multirow[t]{7}{*}{ Perciformes } & Carangidae & Caranx hippos \\
\hline & & Trachinotus teraia \\
\hline & Gerreidae & Eucinostomus melanopterus \\
\hline & Haemulidae & Pomadasys jubelini \\
\hline & & Pomadasys rogerii \\
\hline & Sciaenidae & Pseudotolithus elongatus \\
\hline & & Pseudotolithus senegalensis \\
\hline
\end{tabular}

Table 5: continuation and end

\begin{tabular}{|c|c|c|}
\hline Ordres & Familles & Espèces \\
\hline & Polynemidae & Polydactylus quadrifilis \\
\hline & Monodactylidae & Monodactylus sebae \\
\hline & Mugilidae & Liza falcipinnis \\
\hline & & Mugil cephalus \\
\hline & & Mugil curema \\
\hline & Cichlidae & Chromidotilapia guntheri \\
\hline & & Hemichromis fasciatus \\
\hline & & Sarotherodon melanotheron \\
\hline & & Tilapia guineensis \\
\hline & & Tilapia mariae \\
\hline & & Tylochromis jentinki \\
\hline & Gobiidae & Bathygobius soporator \\
\hline & Sphyraenidae & Sphyraena afra \\
\hline Pleuronectiformes & Channidae & Parachanna obscura \\
\hline & Paralichthyidae & Citharichthys stampflii \\
\hline Total 8 & Cynoglossidae & Cynoglossus senegalensis \\
\hline & 25 & 45 \\
\hline
\end{tabular}

\subsubsection{Numerical Abundance}

Perciformes dominate the fish catches on the Aghien Lagoon with a proportion of $52 \%$. They are followed by Siluriformes
(19\%), Elopiformes (9\%) and Clupeiformes (7\%). The other orders account for $13 \%$ of this population (Figure 6). At the family level, the Cichlidae (32\%) are the most represented in 
the catches. The Claroteidae (14\%), Elopeidae (9\%), Clupeidae $(8 \%)$ and Polynemidae $(7 \%)$ are next. The other families represent $30 \%$ of the fish population (Figure 7). At the species level, Tilapia guineensis is the most abundant species in the Aghien Lagoon with $12 \%$ of all fish caught.
This species is followed by Elops Lacerta and Chrysichthys nigrodigitatus (9\% each), Sarotherodon melanotheron (8\%), Tylochromis jentinki and Polydactylus quadrifilis (7\% each). The other species represent $48 \%$ of this total number (Figure 8)

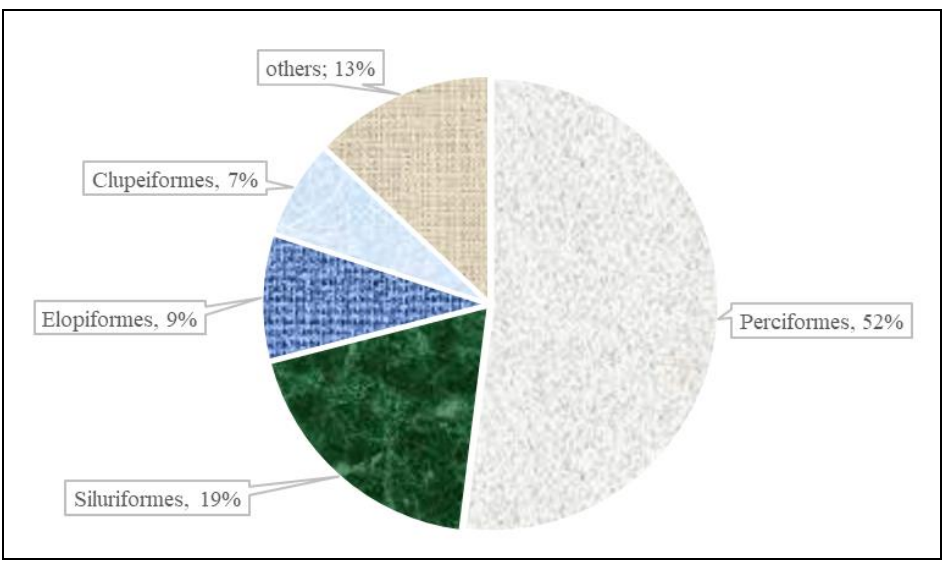

Fig 6: Numerical percentage of major fish orders caught in Aghien Lagoon from April 2019 to March 2020.

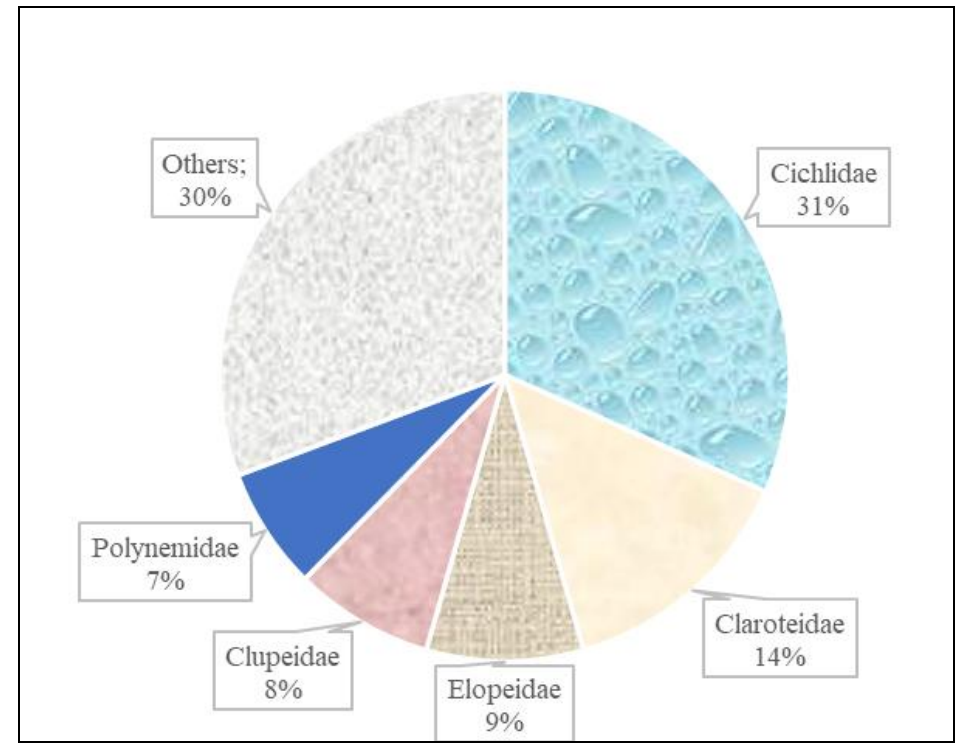

Fig 7: Numerical percentage of major fish families caught in Aghien Lagoon from April 2019 to March 2020

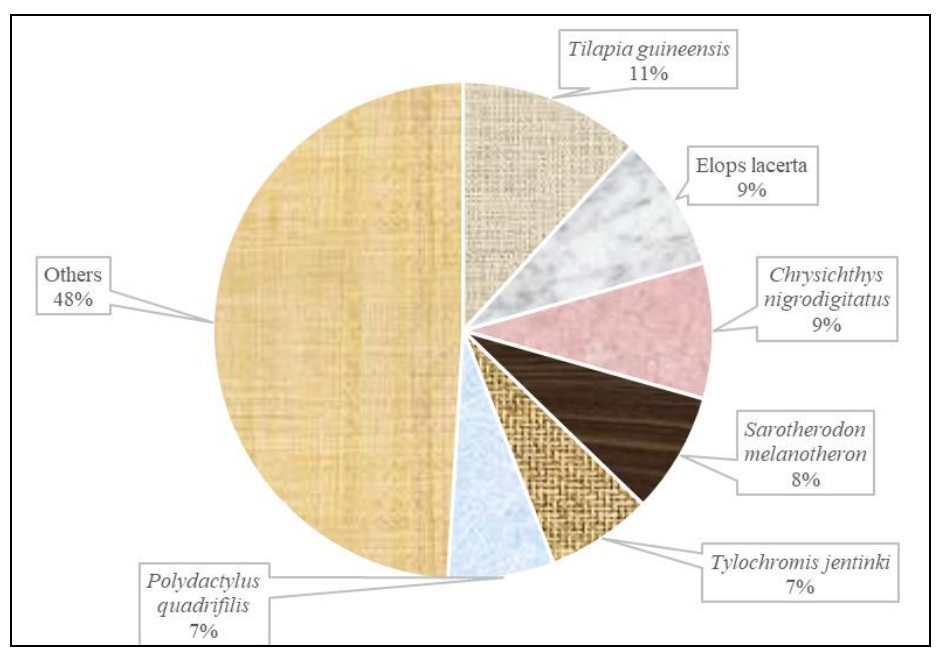

Fig 8: Numerical percentage of major fish species caught in Aghien Lagoon from April 2019 to March 2020

\subsubsection{Weight abundance}

In the Aghien Lagoon, the best represented orders are the Perciformes with $48 \%$. This is followed by the Siluriformes and Clupeiformes (19\% each) and the Elopiformes (9\%) of the total weight of the catches. The proportion by weight of the other orders is 5\% (Figure 9). 
The family Clupeidae is the best represented with $19 \%$ of the total catch. This family is followed by Claroteidae $(18 \%)$, Cichlidae (14\%), Elopeidae (9\%) and Haemulidae (7\%). The other families constitute $33 \%$ of the weight percentage (Figure 10).
At the species level, the dominant species are in order Chrysichthys nigrodigitatus (17\%), Ethmalosa fimbriata (10\%), Elops lacerta and Pellonula leonensis (9\%), Pomadasys jubelini (7\%) and Polydactylus quadrifilis (6\%). The proportion of other species was $42 \%$ (Figure 11)

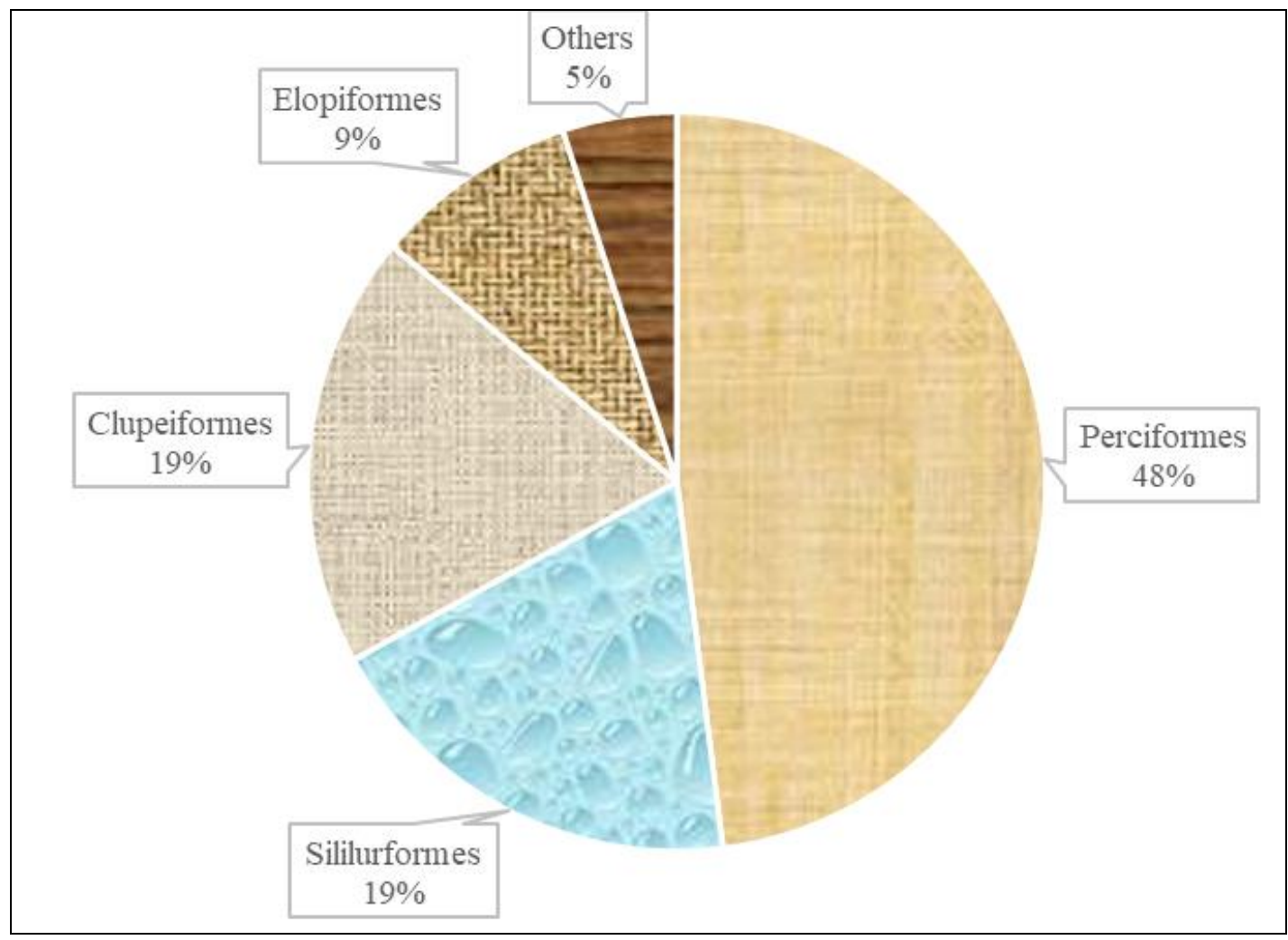

Fig 9: Weight percentage of major fish orders caught in Aghien Lagoon from April 2019 to March 2020

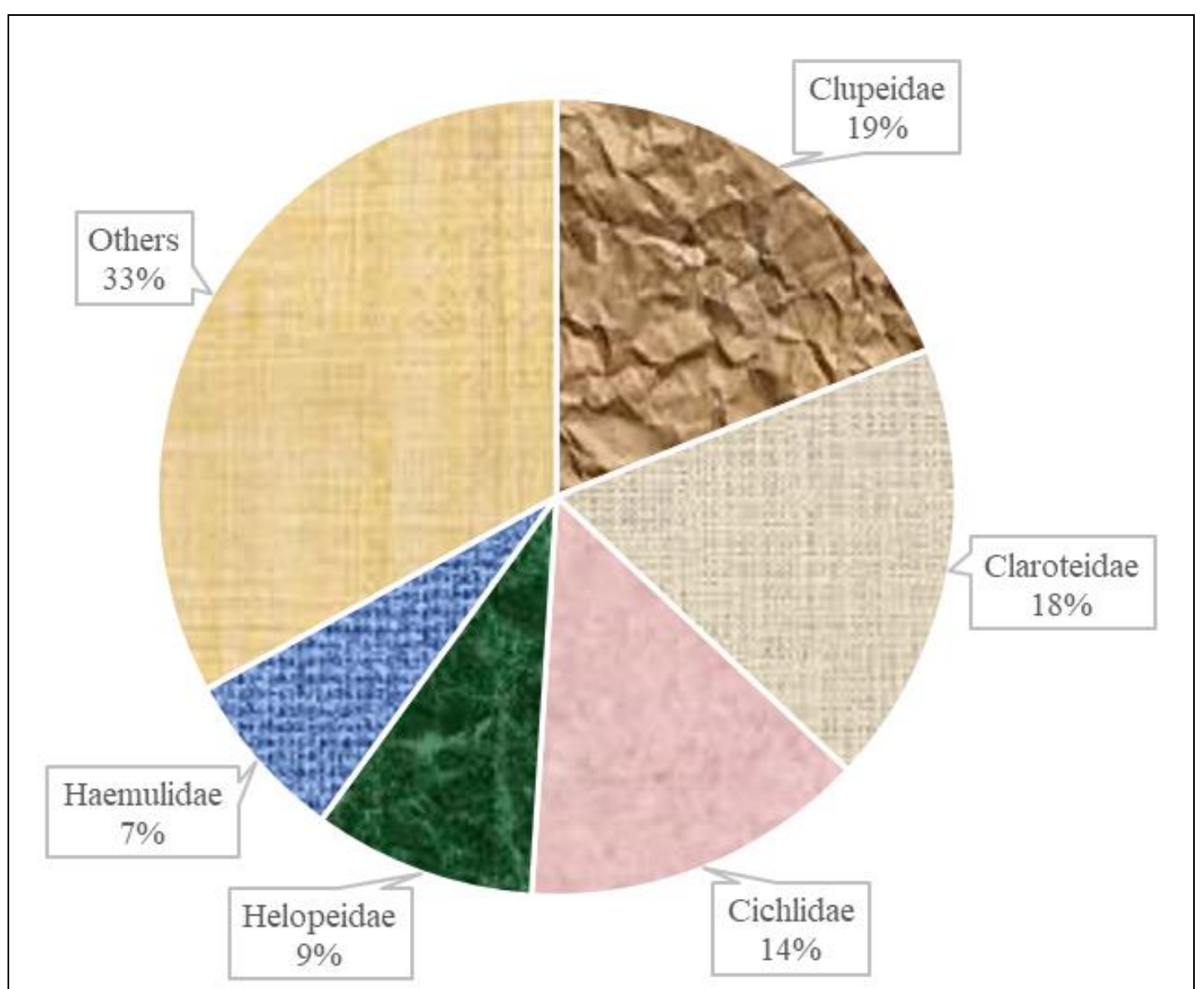

Fig 10: Weight percentage of major fish families caught in Aghien Lagoon from April 2019 to March 2020. 


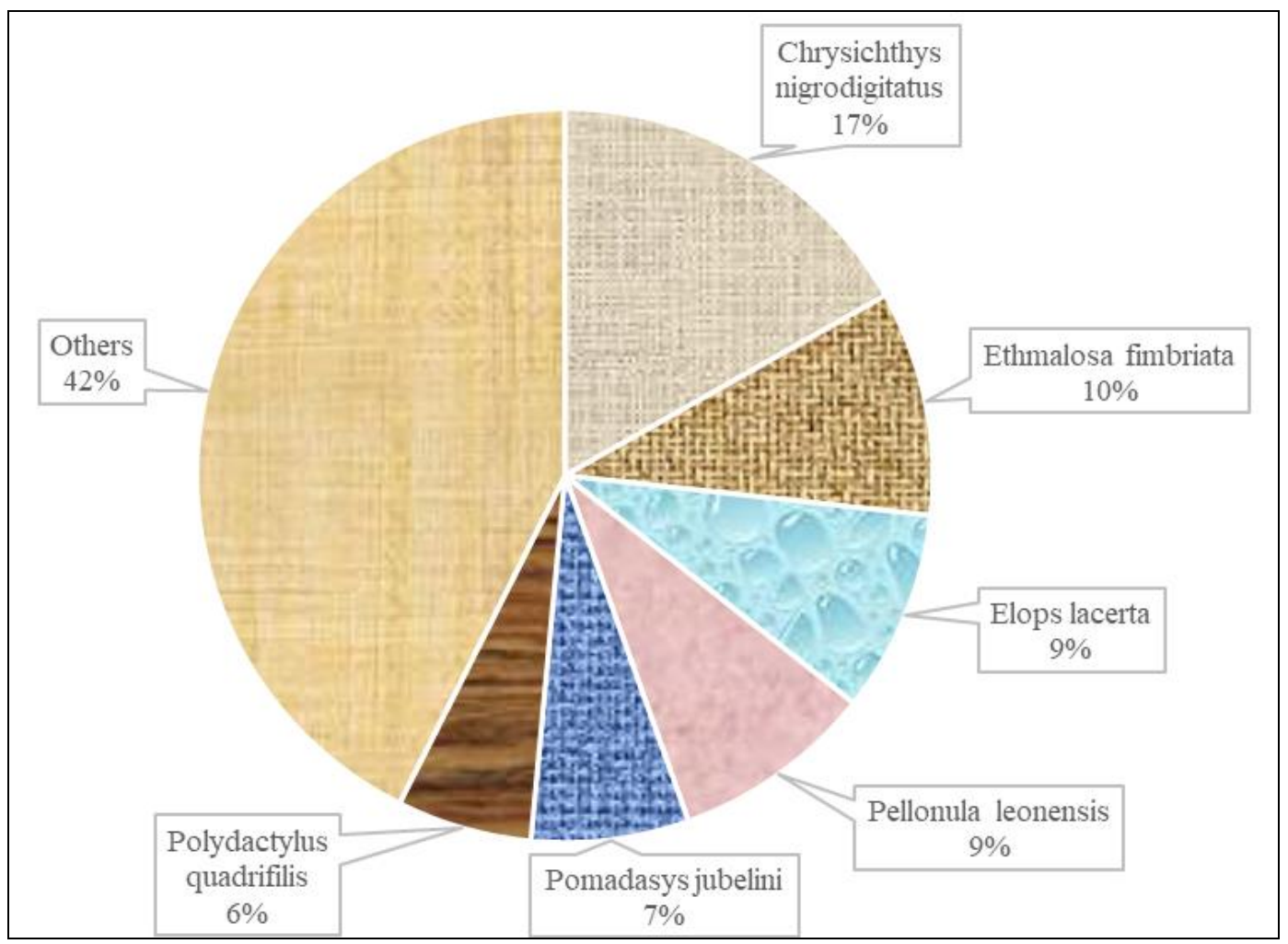

Fig 11: Weight percentage of major fish species caught in Aghien Lagoon from April 2019 to March 2020.

\section{Discussion}

In the Aghien lagoon, fishing is carried out by foreigners and Ivorians, the majority of whom are adults (48.26\%) with a low participation of youth $(25.12 \%)$. This result is consistent with those of several studies characterizing fishing communities in Ivory Coast ${ }^{[1,6,10]}$. The presence of foreign fishers could be explained by several reasons: (1) the proximity of their country of origin to Ivory Coast; (2) the ethnic and social characteristics of these fishermen are sometimes very similar to those encountered in Ivory Coast; (3) the high demand for fish, which is likely to guarantee an attractive price, is quite motivating for these foreign fishermen (Vanga, 2001) ${ }^{[6]}$; and (4) the existence in Ivorian legislation, of few binding provisions for foreign fishermen (Kien et al., 2015) ${ }^{[10]}$. The variable age would condition the professional conscience among fishermen. Indeed, the low enthusiasm of most young people can be explained by the fact that beyond their lack of experience in commercial fishing, they believe that the activity in question is not an asset that they can leave as an inheritance to their descendants. In this case, fishing constitutes a means of acquiring financial resources for the development of agricultural activities (Kien et al., $2015^{[10]}$ and Goli Bi et al., $2019^{[11]}$. The results of the present study show that $50.50 \%$ of fishermen associate fishing with agriculture and among them $49.25 \%$ of Ivorians. This behaviour of fishermen would result from the fact that Ivorians have a tradition of subsistence fishing (Laë, 1997) ${ }^{[12]}$. In terms of type of gear, the occasional fishermen, mostly Ivorians, prefer gill nets $(94.37 \%)$ to bamboo traps $(91.77 \%)$, longlines $(89.61 \%)$ and pots $(88.31 \%)$. This trend is contrary to the results obtained by Boguhé et al. (2011) ${ }^{[9]}$, Kien et al. (2015) ${ }^{[10]}$ and Goli Bi et al. (2019) [11] talking about the Ivorian fishing community. This change in practice clearly shows that Ivorians now accept the gill net technique with courage; a courage that they lacked because they found the management of this type of gear too constraining and preferred traps and bamboo traps that were less expensive, simple to manage and handle (Kien, 2016) ${ }^{[4]}$. The study of the selectivity of fishing gears shows that Chrysichthys nigrodigitatus is the only one caught by five gears out of the six. This result expresses the pressure on this species. This situation could threaten, in the long term, the qualitative availability of fishery resources, leading to an imbalance in the population to the benefit of tilapia (Vanga, 2001) ${ }^{[6]}$. It would therefore be important to consider sustainable management plans for the fishery resource on this body of water.

\section{Conclusion}

The exploitation of fishery resources on the Aghien lagoon is artisanal and individual. It is dominated by occasional, mostly literate, adult fishermen. Among the Ivorians, fishing is mainly a secondary activity. Gill nets are the most widely used engines in the Aghien lagoon. Chrysichthys nigrodigitatus is the most common species in the catches of various gears taken on this lagoon. Sustainable management of resources requires the authorities to carry out strict measures to prevent the collapse of the stock of this species and therefore an imbalance in this ecosystem. The conduct of any fisheries development policy must take into account the low level of education of certain actors.

\section{References}

1. Situation mondiale des pêches et de l'aquaculture. Contribuer à la sécurité alimentaire et à la nutrition de tous. FAO, Rome, 2016, 37.

2. Fabio P, Njifonjou O, Assienan J, Kodjo A, Ndia Y, Salvati $\mathrm{N}$ et al. Profil de pauvreté des communautés riveraines du lac de Kossou en Côte d'Ivoire. Cotonou, Programme pour des Moyens d'Existence Durables dans la Pêche en Afrique de l'Ouest, PMEDP/RT 2002,17.

3. Blahoua KG, Adou YE, Kouamé KA, N'Douba V. «Typologie de la pêche sur le lac de barrage d'Ayame 2 (Côte d'Ivoire, Afrique de l'0uest), » International 
Journal of Innovation and Scientific Research 2018;36(2):178-185.

4. Kien KB. Activité de pêche sur le fleuve Bandama (Côte d'Ivoire): impact sur l'organisation du peuplement de poisson $\mathrm{du}$ cours inférieur et conséquences socioéconomiques. Thèse de Doctorat, Université Félix HOUPHOUËT-BOIGNY, Abidjan, Côte d'Ivoire 2016, 206.

5. Bedia AT, N'Zi KG, Yao SS, Kouamelan EP, N'douba V, Kouassi N. J. Typologie de la pêche en lagune Aghien-Potou (Côte d'Ivoire, Afrique de l'Ouest): acteurs et engins de pêche. Agronomie Africaine 2009;21(2):197-204.

6. Vanga AF. Conséquences socio-économiques de la gestion des ressources naturelles: cas des pêcheries dans les lacs d'Ayamé et de Buyo (Côte d'Ivoire). Thèse de Doctorat, Université d'Abobo-Adjamé, Abidjan, Côte d'Ivoire 2001, 210.

7. Vanga AF. Conséquences socio-économiques de l'expulsion des pêcheurs étrangers en Côte d'Ivoire: lacs d'Ayamé et de Buyo. Revue Européenne Des Migrations Internationales 2004;20(1):197-205.

8. Tah L, Da Costa KS, Kouassi NJ, Moreau J. Preliminary assessment of major Tilapiine fishes exploited by artisanal gillnet fishery in Lake Ayamé I (Bia basin, Côte d'Ivoire). Journal of Fisheries International 2009;4(4):8390.

9. Boguhé GFDH, Goore Bi G, N'Zi KG, Yao SS, Kouamelan EP, Kouassi NJ. Premières données sur la pêche crevettière du fleuve Bandama (Côte d'Ivoire): acteurs et engins de pêche. Sciences et Nature 2011;8(1):107-118.

10. Kien KB, Yao SS, Vanga AF, Kouamélan EP. "Typologie de la Pêche sur le cours inférieur du fleuve Bandama (Côte d'Ivoire, Afrique de l'Ouest)," International Journal of Innovation and Applied Studies 2015;13(1):67-77.

11. Goli Bi BEP, Kien KB, Kamelan TM, Berte S, Kouamelan EP. Typologie de la pêche sur le lac de barrage de Buyo (fleuve Sassandra, Côte d'Ivoire). International journal of innovation and Applied Studies 2019;26(4):1220-1229.

12. Laë R. Effects of climatic changes and developments on continental fishing West Africa: the examples of the Central Delta of the Niger in Mali and coastal lagoons in Togo. In: African inland fisheries, aquaculture and the environment. (Farham R. K., éd). Fishing News Books 1997;66-86. 